\title{
Black Oxide Nanoparticles as Durable Solar Absorbing Material for High-Temperature Concentrating Solar Power System
}

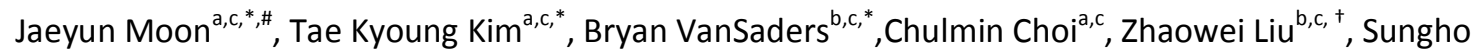 \\ $\operatorname{Jin}^{\mathrm{a}, \mathrm{c},}{ }^{+}$, and Renkun Chen ${ }^{\mathrm{a}, \mathrm{c},{ }^{+}}$ \\ ${ }^{a}$ Department of Mechanical Engineering, ${ }^{b}$ Department of Electrical and Computer Engineering, ${ }^{c}$ \\ Materials Science and Engineering Program \\ University of California, San Diego, La Jolla, CA 92093, USA \\ *These authors contributed equally to this work \\ † Corresponding Authors: \\ E-mail: zhaowei@ucsd.edu; jin@ucsd.edu; rkchen@ucsd.edu
}

Concentrating solar power is becoming an increasingly important part of the renewable energy portfolio. However, further cost reduction is desired to make CSP competitive with traditional energy technologies. Higher operating temperature is considered an attractive avenue leading to higher power conversion efficiency and lower cost, but tremendous technical challenges exist with higher temperature operation of CSP, with one of the main issues being the lack of a high-performance solar absorbing material that is durable at $750{ }^{\circ} \mathrm{C}$ or above. In this work, a black oxide material, made of cobalt oxide nanoparticles, is synthesized and utilized as a high-temperature solar absorbing material. The nanoparticles are embedded in a dielectric matrix through a scalable spray coating process. The top layer of the coating is further improved with light-trapping structures using sacrificial fillers introduced from the same coating process. After the surface modification of cobalt oxide coating, we achieved a high thermal efficiency of $88.2 \%$. More importantly, the coating shows no degradation after 1,000-hour annealing at $750{ }^{\circ} \mathrm{C}$ in air, while the existing commercial light absorbing coating was reported to degrade by long-term exposure at high temperature. Our findings 
suggest that the materials and processes developed here are promising for solar absorbing coating for future high-temperature CSP systems.

Keywords: concentrating solar power, solar absorber, cobalt oxide, light trapping, high temperature

\section{Introduction}

The development and deployment of r_ENREF_1_ENREF_2enewable energy sources is becoming an increasingly urgent need for human society $[1,2]$. Concentrating solar power (CSP) systems (or solar thermal systems) are becoming an important part of the major portfolio of renewable energy generation. One of the key potential advantages of CSP over many other forms of the renewables is the possibility of inexpensive energy storage using thermal energy storage systems (TES), which is useful for grid-level power management [3]. The TES can extend the electricity generation capability to periods with no sunlight available, thereby significantly expanding the value and usage of solar energy [4]. CSP systems can also be hybridized with other alternative energy systems, such as solar

photovoltaic [5], thermoelectric $[6,7]$, or thermophotovoltaic $[8,9]$ systems, to increase the penetration of renewable energy power $[10,11]$. Despite these perceived benefits, the levelized cost of energy (LCOE) of CSP, however, is still too high to compete with traditional thermal power plants and some other alternative energy technologies (such as photovoltaics) [12].

In order to develop a cost-competitive CSP technology, it is imperative to increase the system power conversion efficiency. To maximize the efficiency of CSP, it is desirable to raise the operating temperature for higher Carnot efficiency. As a result, the temperature of heat transfer fluids (HTFs) needs to be $700^{\circ} \mathrm{C}$ or higher [13]. Toward this aim, all of the components of CSP systems, such as solar field, HTFs, power block, TESs, and solar receivers need to be made compatible with the higher-temperature operation. 
_ENREF_7As far as the solar receiver is concerned, the light-absorbing coatings on the receiver

play an important role by absorbing solar thermal energy and raising the temperature of the HTFs to above $700^{\circ} \mathrm{C}$. Although spectrally selective coatings (SSCs) with multilayers/graded cermets or tandem structures have been developed and stably operated in vaccum in parabolic trough CSP systems [14-19], none of these SSC structures can operate at high temperatures in air, which is needed in future solar-tower based CSP systems. The state-of-the-art solar absorbing material used in solar towers is based on a commercially available black paint called Pyromark $2500^{\circ}$. Pyromark $2500^{\circ}$ is known to have high thermal efficiency above $600{ }^{\circ} \mathrm{C}$ and has been used for central solar receivers of CSP plants. However, according to prior studies, the absorptivity degraded after high temperature $\left(>700^{\circ} \mathrm{C}\right)$ exposure due to crystal structure changes and phase instability $[20,21]$. Therefore it is clear that a new light absorbing coating material with high absorption efficiency and excellent durability at elevated temperature in air environment needs to be developed for the next generation CSP systems.

Since the light absorption is directly related to solar energy generation efficiency, a large number of studies about optical absorption enhancement have been actively pursued. Several light trapping approaches were studied, such as texturing [22-25], metalolic nanostructures [26], and photonic [2729] and plasmonic structures [30, 31]. However, most of these studies about light trapping have been applied on photovoltaic applications using vacuum deposition methods. As the result, these processes are not necessarily compatible with CSP applications, where spray coating is generally employed to coat the light absorbing layers [21,32] onto solar tower receivers, for example, Pyromark $2500^{\circ}$ in Solar One and Solar Two central towers [33, 34].

Here, we report a highly efficient and high-tempeature durable light absorbing coatings based on cobalt oxide nanoparticles for CSP receivers. Cobalt oxide materials have been studied as selective absorbing layers and fabricated using spray pyrolysis method [35-37], chemical vapor deposition [38] and electrodeposition. Although several previous studies showed the applicability as solar collectors 
within the temperature range of $300^{\circ} \mathrm{C}^{\sim} 650^{\circ} \mathrm{C}$ [39-41], there is no existing light absorbing coating suitable for CSP operating at higher temperature $\left(\sim 750^{\circ} \mathrm{C}\right)$ without performance degradation. In this study, the cobalt oxide nanoparticles were synthesized via a facile hydrothermal process and utilized as the light-absorbing material in the coating layers. The coating layers consist of cobalt oxide nanopowders dispersed in silica matrix, and are deposited on metal substrates via a simple and scalable spray coating process, which is compatible with CSP applications. We employed novel and yet simple surface texturing techniques, based on sacrificial polymer beads that can be easily integrated with the spray coating process, to improve the light absorption. Finally, the developed coating layer exhibited unprecedented high-temperature durability, showing no degradation in structural or optical properties after annealing at $750^{\circ} \mathrm{C}$ in air for 1,000 hours.

\section{Experimental}

\subsection{Cobalt oxide nanoparticle synthesis and sample preparation}

We first aimed at synthesizing cobalt oxide nanoparticles of right sizes for high light absorption. For nanoparticles (aspect ratio 1), the optimal size for absorbing visible and near infrared light is probably around $200 \sim 400 \mathrm{~nm}$ [42]. If the particle size was too small, the resultant coating film would have small surface roughness, which is not effective for light trapping. In addition, for high temperature application, very small nanoparticles $(<100 \mathrm{~nm})$ would agglomerate and become larger size particles. Therefore, we aimed at producing nanoparticles with 100s of nanometers in diameter. Metal oxide nanoparticles can be prepared by a number of different methods, such as sol-gel technique [43], mechanical grinding (ball milling) [44], mechanochemical synthesis [45], and hydrothermal synthesis [46], etc. Here we utilized the hydrothermal method to synthesize $\mathrm{Co}_{3} \mathrm{O}_{4}$ nanoparticles for convenience. However, it should be noted that other inexpensive nanoparticle synthesis techniques mentioned above may also be used for producing metal oxides for SSC applications.

Cobalt oxide nanoparticles were synthesized via a hydrothermal process using cobalt chloride salt $\left(\mathrm{CoCl}_{2} \cdot 6 \mathrm{H}_{2} \mathrm{O}\right)$ as the precursor. $10 \mathrm{M}$ solution of sodium hydroxide $(\mathrm{NaOH})$ was gradually dropped into 
$1 \mathrm{M}$ solution of cobalt chloride to induce precipitation of cobalt hydroxide until $\mathrm{pH}$ value of the reacted solution reached 11 . The hydrothermal synthesis was performed at $150^{\circ} \mathrm{C}$ for 20 hours in order to transform the precipitated cobalt hydroxide into cobalt oxide. The cobalt oxide particles were then washed with de-ionized water using a centrifuge and dried using a freeze-dryer. The assynthesized nanoparticles were annealed at $750^{\circ} \mathrm{C}$ for 2 hours for phase stabilization.

For the fabrication of $\mathrm{Co}_{3} \mathrm{O}_{4}$ slurry, methyl phenyl polysiloxane resin (SILIKOPHEN ${ }^{\circledR}$ P 80/X) was utilized as precursor of $\mathrm{SiO}_{2}$ matrix. The volume ratio between the active material (cobalt oxide nanopowders) and the $\mathrm{SiO}_{2}$ matrix was systematically varied and optimized. The required amount of resin was diluted with an organic solvent mixture consisting of two miscible solvents, xylene and isobutanol (volume ratio 3:1). The optimum dilution was important to ensure good quality of the coating layers, because too viscous slurry could not make a smooth spray stream while very dilute slurry could not make a stable spray-coating onto substrates. In order to dissolve the resin in the solvent, the mixture was sonicated for 30 minutes with a probe type sonicator. During sonication, the solution container was cooled in an ice-bath to avoid concentration change due to the evaporation of organic solvents. $\mathrm{Co}_{3} \mathrm{O}_{4}$ powders were mixed with the prepared solution and yttria stabilized zirconia (YSZ) grinding balls were also added into the blend. The ball milling was conducted for 24 hours in order to make the mixture homogeneous.

The black oxide spray coating was performed using a spray gun on a high temperature Ni alloy (Inconel 625) sheet coupons $(1 / 2 " \times 1 / 2 "$ in size). The spray pressure was set at $40 \mathrm{psi}$ and the distance between the spray gun and the Inconel substrate is about $10 \mathrm{~cm}$, which has been optimized for the best coating quality. After spray coating, the samples were heated at $250^{\circ} \mathrm{C}$ for 1 hour for curing of $\mathrm{SiO}_{2}$ resin. All of the coating samples consist of two layers: the base layer of approximately $30 \mu \mathrm{m}$ thick and a top layer with surface-topography-modified structure described in the next paragraph. 


\subsection{Cobalt oxide surface texturing}

The first method to alter the surface texturing and topography of the top layer to improve optical absorption was to employ imprinting stamps with SU-8 polymer pillars which were prepared by using standard microfabrication processes. The polymer pillars were $3 \mu \mathrm{m}$ in both diameter and spacing and $10 \mu \mathrm{m}$ in height. The stamps were then pressed onto coated $\mathrm{Co}_{3} \mathrm{O}_{4}$ coating surface and left as imprinted prior to the resin curing step. Then, the sample was annealed at $750^{\circ} \mathrm{C}$ for 1 hour to burn away the remaining polymer pillars.

The second method employed to create roughened surface is by incorporating and subsequently removing micron-sized sacrificial polymeric beads within the $\mathrm{Co}_{3} \mathrm{O}_{4}$ coating layer. The volumetric concentration of $\mathrm{CO}_{3} \mathrm{O}_{4}$, polymer beads and silicone resin was optimized to yield the best optical performance (as shown in Table 1), and the mixtures were again sonicated with a probe type sonicator for proper mixing. Then, a desired amount of silicone resin was added, followed by the same ball milling and spray coating processes described in the prior paragraphs. Finally, the coated layers were annealed at $750^{\circ} \mathrm{C}$ for 1 hour to remove the polymeric beads and leave behind the porous and topographically rough top surface of $\mathrm{CO}_{3} \mathrm{O}_{4}$ layer.

\subsection{Optical performance and high temperature endurance evaluation}

The thermal efficiency of a solar receiver, which measures the ratio of the energy absorbed relative to the incident solar energy, and FOMs can be calculated from Eq. 1.

$$
F=\frac{\int_{0}^{\infty}(1-R(\lambda)) I(\lambda) d \lambda-\frac{1}{C}\left[\int_{0}^{\infty}(1-R(\lambda)) B(\lambda, T) d \lambda\right]}{\int_{0}^{\infty} I(\lambda) d \lambda}
$$

where $R(\lambda)$ is the spectral reflectivity, $I(\lambda)$ is the spectral solar radiance per square meter as defined by the reference solar spectral irradiation(ASTM G173), $B(\lambda, T)$ is the spectral thermal emission of a black body at temperature $T$, and $C$ is the concentration ratio. In the calculations used in this study, the black body temperature $T$ of the solar receiver is assumed to be $750^{\circ} \mathrm{C}$ and $\mathrm{C}$ is assumed to be 1,000 (1,000 sun), which are the target temperature and concentraion ratio, respectively, for 
enhanced efficiency of CSP systems. All of the integrals to calculate FOMs are evaluated in the range from $300 \mathrm{~nm}$ to $20 \mu \mathrm{m}$, as only negligible quantities of solar power are present outside this range. Reflection data were measured at room temperature using a Labsphere ${ }^{\circledR} 4 "$ integration sphere to collect all angles of reflection from samples and Andor $^{\circledR} 303$ i spectrometer equipped with a Si based (spectral range 300-1100nm) and InGaAs based (spectral range $900 \mathrm{~nm}-2500 \mathrm{~nm}$ ) detector. Reflection behavior of samples outside of the measured spectral range of $400 \mathrm{~nm}-2.5$ um was extrapolated for use in Eq. 1. While the reflection data were measured at room temperature, it is highly desirable to obtain the reflection spectra at the actual operating temperature of $\sim 750^{\circ} \mathrm{C}$. High temperature optical measurement in non-vacuum environment is highly challenging due to the heat conduction and possible damage to lenses, integration sphere, and other optical system parts. Such measurements will be attempted with improved design of the optical measurement system in progress, which will be reported in future publications.

To characterize the durability of the coating at elevated temperature, the long-time annealing tests at $750^{\circ} \mathrm{C}$ in air were carried out on the coated samples as well as the $\mathrm{Co}_{3} \mathrm{O}_{4}$ nanopowders with the annealing time up to 1,000 hours. The composition of the material before vs after the annealing was analyzed using XRD (Bruker D8 Discover) using a scan speed of $0.037^{\circ} \mathrm{s}^{-1}$ in the $2 \theta$ range of $20^{\sim} 80^{\circ}$; the structural integrity was examined using optical microscope and SEM (Phillips XL30 FEG); the thermal stability of $\mathrm{CO}_{3} \mathrm{O}_{4}$ phase at high temperature $\left(750^{\circ} \mathrm{C}\right)$ in air was also evaluated using thermogravimetric analysis (TGA, TA Instruments SDT Q600) with air of $20 \mathrm{ml} / \mathrm{min}$ flow rate; finally, the optical properties of the samples were measured with the same procedure as above.

\section{Results and Discussion}

\subsection{Cobalt Oxide Nanopowders Synthesis and Coating Process}


Cobalt oxide nanoparticles were synthesized by the hydrothermal process. Both the assynthesized and annealed cobalt oxide nanoparticles were examined with scanning electron microscopy (SEM). The diameter of the as-synthesized powders ranges from 100 to $300 \mathrm{~nm}$ after stabilizing heat treatment, as shown in Fig. 1(a). According to X-ray diffraction (XRD) analysis shown in Fig.1(b), the synthesized chemical compound is confirmed as $\mathrm{Co}_{3} \mathrm{O}_{4}$, which is one of the polymorphs of cobalt oxide $[47,48]$. Pure $\mathrm{CoO}$ is difficult to synthesize, because $\mathrm{CoO}$ can easily acquire oxygen and convert to a higher level oxide. While $\mathrm{Co}_{2} \mathrm{O}_{3}$ can be created when the cobalt compounds are annealed at a low temperature, it can easily be converted to $\mathrm{Co}_{3} \mathrm{O}_{4}$ when heated above $538 \mathrm{~K}$ in oxygen-containing environment [49]. Therefore, we have concentrated our effort on the most stable form of cobalt oxide, i.e., $\mathrm{Co}_{3} \mathrm{O}_{4}$. The coating process was carried out using a gravity-feed spray gun. All of the coating layers were deposited onto high-temperature Inconel substrate (type 625) coupons $\left(1 \frac{1}{2} " \times 1 / 2\right.$ " in area) pre-treated with sand blasting. Inconel was chosen because it is currently used for high-temperature CSP due to its high-temperature durability [50]. The schematic diagram of the coated structure is shown in Fig. 2(a), and the photographs of a bare Inconel substrate and a sample coated with a $\mathrm{Co}_{3} \mathrm{O}_{4}$ layer are shown in Fig. 2(b).

\subsection{Light Absorbing Coating Structure Modification}

Fig. 3(a) and (b) show SEM images of $\mathrm{CO}_{3} \mathrm{O}_{4}$ coating layer without and with embedded hole patterns (pores), respectively. The measured specular reflectance of the coating within the spectral range of $400 \mathrm{~nm}$ to $2 \mu \mathrm{m}$ was shown in Fig. 3(c) and the FOM was calculated according to Eq. 1 . The FOMs of the non-patterned and patterned coatings are 0.8542 and 0.8730 , respectively. The suppressed reflectance due to the patterned sample led to $2.2 \%$ increase in FOM, which is substantial and can be attributed to enhanced light trapping in the patterned holes_ENREF_20. The incident light goes into the holes and diffracts at oblique angles within the $\mathrm{Co}_{3} \mathrm{O}_{4}$ absorbing coating, thus the light absorption is improved. Previously, computational and experimental studies [28, 51-53] have shown similar optical light-trapping phenomena with various surface patterns, mostly with 
microscale pillars. Even though hole patterns may not be as efficient for scattering light in

comparison to dense vertical pillar array structures due to the smaller surface area that an oblique

light can reach, the process of making hole patterns is easier to implement with the spray coating

process.

After establishing the principle of enhanced light absorption with surface hole patterning, we developed a more scalable process based on sacrificial polymer beads, as described in section 2.2. The details of the samples are provided in Table 1. From the SEM images shown in Fig. 4(a) and (b), the surface roughness of the coating layer was increased after introducing the polymer beads in $\mathrm{Co}_{3} \mathrm{O}_{4}$ coating layer, compared to the original coating (Fig. 3(a)). The increased roughness results in reduced reflectance (Fig. 4 (c)) and enhanced FOMs (Table 1). The FOM of the $\mathrm{CO}_{3} \mathrm{O}_{4}-2$ and $\mathrm{Co}_{3} \mathrm{O}_{4}-3$ samples are increased by $2.7 \%$ and $3.3 \%$, respectively, compared to the initial $\mathrm{CO}_{3} \mathrm{O}_{4}$ sample. The roughened surfaces can be regarded as being close to Lambertian surface, which is defined as a surface reflecting light with equal intensity in all directions, namely diffusely reflecting surface. Similar mechanism has been utilized for enhanced absorption in solar cells, for example, by creating 'black Si' using anisotropic etching of surface [22], hydrogen etching [54], or mechanical grinding [23, 55]. Furthermore, random roughness helps scatter light more efficiently than periodic structure due to a break in mirror symmetries (i.e. suppressed diffractive effects), as the prior simulation studies demonstrated the random or skewed pyramid structures outperformed regular pyramidal texturing $[22,56]$. Compared to these reported processes (etching or mechanical grinding), our process of using sacrificial polymer beads can be easily integrated with the spray coating process without any additional micromachining steps, with the polymer particles automatically burned away to create pores during the subsequent heating to the CSP operating temperature. Therefore, the process developed here is cost-effective and scalable to meet the needs of CSP applications. It is noted from Figs. 3 and 4 that there are reflectance peaks at about $1 \mu \mathrm{m}$ and $1.8 \mu \mathrm{m}$ wavelengths. These peaks are due to inherent optical properties of $\mathrm{CO}_{3} \mathrm{O}_{4}$. According to Ref [57], there are four absorption bands for $\mathrm{CO}_{3} \mathrm{O}_{4}$ in the visible to near-IR range: $0.83 \mathrm{eV}(1.497 \mu \mathrm{m}), 0.94 \mathrm{eV}(1.322 \mu \mathrm{m}), 1.7 \mathrm{eV}(731$ $\mathrm{nm})$ and $2.9 \mathrm{eV}(428 \mathrm{~nm})$. These absorption peaks are associated with different charge transfer processes, as described in detailed in Ref. [57]. Because there is no absorption band immediately close to the $1 \mu \mathrm{m}$ wavelength or above the $1.7 \mu \mathrm{m}$ wavelength, the extinction coefficients are very small around $1 \mu \mathrm{m}$ and beyond $1.7 \mu \mathrm{m}$ [57]. As a result, these reflectance peaks at $1 \mu \mathrm{m}$ and 1.8 $\mu m$ are difficult to eliminate via surface patterning (Fig. 3\&4). However, it is possible to remove these peaks by adding other compositions of metal oxide materials having absorption bands near 1 $\mu \mathrm{m}$ and $1.8 \mu \mathrm{m}$, which is a topic that warrants further investigation.

\subsection{High Temperature Stability of $\mathrm{Co}_{3} \mathrm{O}_{4}$ Light Absorbing Coating}

The receiver coating in the next generation CSP systems should possess not only high thermal efficiency but also high temperature stability because of the anticipated trend of higher operating temperature (above $700-750^{\circ} \mathrm{C}$ ) [58, 59]_ENREF_26. The high-temperature stability of the coating 
depends on both the intrinsic material properties (e.g., phase transformation at high temperature) and structural integrity of the porous coating, as well as its adhesion to the substrate. We carried out the high-temperature annealing test in air as described in Section 2 for both the coating sample and the nanopowders. For the coated sample, the one with 1:5 volume ratio of cobalt oxide powders to polymer beads $\left(\mathrm{Co}_{3} \mathrm{O}_{4}-3\right)$ was used because it showed the best FOM in this study.

The microstructural and_ENREF_26XRD analysis results are displayed in Fig. 5. Fig. 5(a) and (b) show the SEM images of the nanoparticles after the $750^{\circ} \mathrm{C}$ annealing in air. The images indicate that the surface roughness was not changed and the nanopowders were not agglomerated upon annealing, demonstrating the structural stability of the material. Fig. 5(c) shows the XRD results of the sample before and after the annealing. The XRD diffraction peaks for all the three samples (asprepared, 100-hr annealing, and 1000-hr annealing) indicate that the samples consist of identical single phase $\mathrm{Co}_{3} \mathrm{O}_{4}$. The evaluation of phase stability of $\mathrm{Co}_{3} \mathrm{O}_{4}$ nanopowders at $750^{\circ} \mathrm{C}$ in air was also made using TGA analysis as shown in Fig. 6 , which shows that $\mathrm{Co}_{3} \mathrm{O}_{4}$ nanopowders gain weight by $\sim 0.5 \mathrm{wt} \%$ in the process of temperature ramping up to $750^{\circ} \mathrm{C}$ in air and the weight change becomes negligible ( $0 \mathrm{wt} \%$ change) during the annealing at $750^{\circ} \mathrm{C}$ for 2 hours. The initial weight gain is presumably due to the full conversion of residual $\mathrm{CoO}$ to $\mathrm{Co}_{3} \mathrm{O}_{4}$, after which the weight gain is essentially zero, showing the stability of the $\mathrm{Co}_{3} \mathrm{O}_{4}$ nanopowders. These results clearly show that the cobalt oxide nanopowders synthesized by the hydrothermal process in this study were stable at the set temperature of $750^{\circ} \mathrm{C}$. Cobalt usually forms two oxide structures, namely, $\mathrm{CoO}$ with $\mathrm{NaCl}$ crystal structure and $\mathrm{CO}_{3} \mathrm{O}_{4}$ with spinel structures [60]. According to the thermodynamic diagram of the $\mathrm{Co}-\mathrm{O}$ system, $\mathrm{Co}_{3} \mathrm{O}_{4}$ was a stable phase at $750^{\circ} \mathrm{C}$ in ambient atmosphere $\left(0.21 \mathrm{~atm} \mathrm{O}_{2}\right.$ partial pressure) [48]. In this environment, $\mathrm{Co}_{3} \mathrm{O}_{4}$ is stable from room temperature up to $840^{\circ} \mathrm{C}$ and converts to $\mathrm{CoO}$ above $840^{\circ} \mathrm{C}$.

Finally, we show the FOMs of the best-performing samples with 1:5 volume ratio of black oxide powders to polymer beads (designated as $\mathrm{Co}_{3} \mathrm{O}_{4}-3 \mathrm{~A}$ and $\mathrm{Co}_{3} \mathrm{O}_{4}-3 \mathrm{~B}$ samples) after various annealing durations ranging from 0 to 1,000 hours in Fig. 7 . The result clearly demonstrates that the 
FOM remains the same after 1,000 hours of high temperature exposure, indicating that the main features of the high optical performance, including cobalt oxide phase composition, surface roughness and porous structure were still intact after extended annealing. Therefore, $\mathrm{Co}_{3} \mathrm{O}_{4}$ black oxide is a promising solar absorption candidate material for $750^{\circ} \mathrm{C}$ CSP operating environment. In contrast, Pyromark coating, which is the state of the art coating for CSP applications, shows 3\% degradation of solar absorptance at $750^{\circ} \mathrm{C}$ after 300 hours [21].

\section{Conclusion}

In summary, we have synthesized $\mathrm{Co}_{3} \mathrm{O}_{4}$ black oxide nanoparticles using a facile hydrothermal process and developed novel designs and fabrication processes of light-absorbing coating structure for high-temperature CSP systems. By introducing sacrificial polymer fillers into the nanopowder-based coating slurry, the surface texturing was successfully obtained and the optical performance was enhanced, as measued by a high figure of merit of $88.2 \%$. For high temperature durability, a long-term aging test was performed and the results revealed that the light-trapping structure remained intact after $750^{\circ} \mathrm{C}$ exposure in air for 1,000 hours. Consequently, the FOM showed negligible change after the 1,000-hour exposure.The findings suggest that the textured $\mathrm{CO}_{3} \mathrm{O}_{4}$ coating is a promising candidate for solar absoring in next-generation high-temperature CSP systems. The $\mathrm{CO}_{3} \mathrm{O}_{4}$ layer can easily be spray-coated in a manner suitable for large-scale CSP receiver applications.

\section{Acknowledgements}

This work is supported by US Department of Energy, SunShot Program Contract No. DE-EE0005802.

[1] M.I. Hoffert, K. Caldeira, A.K. Jain, E.F. Haites, L.D.D. Harvey, S.D. Potter, M.E.

Schlesinger, S.H. Schneider, R.G. Watts, T.M.L. Wigley, D.J. Wuebbles, Energy implications of future stabilization of atmospheric CO2 content, Nature, 395 (1998) 881-884. 
[2] United States Energy Information Administration (EIA), International Energy Outlook 2013, in, 2013.

[3] R. Sioshansi, P. Denholm, The Value of Concentrating Solar Power and Thermal Energy Storage, IEEE T Sustain Energy, 1 (2010) 173-183.

[4] V. Morisson, M. Rady, E. Palomo, E. Arquis, Thermal energy storage systems for electricity production using solar energy direct steam generation technology, Chem Eng Process, 47 (2008) 499-507.

[5] T.T. Chow, A review on photovoltaic/thermal hybrid solar technology, Appl Energ, 87 (2010) 365-379.

[6] D. Kraemer, B. Poudel, H.P. Feng, J.C. Caylor, B. Yu, X. Yan, Y. Ma, X.W. Wang, D.Z. Wang, A. Muto, K. McEnaney, M. Chiesa, Z.F. Ren, G. Chen, High-performance flat-panel solar thermoelectric generators with high thermal concentration, Nat Mater, 10 (2011) 532538.

[7] Y. Yan, J.A. Malen, Periodic heating amplifies the efficiency of thermoelectric energy conversion, Energ Environ Sci, 6 (2013) 1267-1273.

[8] A. Lenert, D.M. Bierman, Y. Nam, W.R. Chan, I. Celanovic, M. Soljacic, E.N. Wang, A nanophotonic solar thermophotovoltaic device, Nat Nanotechnol, 9 (2014) 126-130.

[9] P. Bermel, M. Ghebrebrhan, W. Chan, Y.X. Yeng, M. Araghchini, R. Hamam, C.H.

Marton, K.F. Jensen, M. Soljacic, J.D. Joannopoulos, S.G. Johnson, I. Celanovic, Design and global optimization of high-efficiency thermophotovoltaic systems, Opt Express, 18 (2010) A314-A334.

[10] P. Denholm, M. Mehos, Enabling Greater Penetration of Solar Power via the Use of CSP with Thermal Energy Storage, in, National Renewable Energy Laboratory, 2011.

[11] P. Denholm, Y.-H. Wan, M. Hummon, M. Mehos, An Analysis of Concentrating Solar Power with Thermal Energy Storage in a California 33\% Renewable Scenario, in, National Renewable Energy Laboratory, 2013.

[12] J. Hernandez-Moro, J.M. Martinez-Duart, CSP electricity cost evolution and grid parities based on the IEA roadmaps, Energ Policy, 41 (2012) 184-192.

[13] G.J. Kolb, C.K. Ho, T.R. Mancini, J.A. Gary, Power Tower Technology Roadmap and Cost Reduction Plan, in, Sandia National Laboratories, 2011.

[14] N. Selvakumar, H.C. Barshilia, Review of physical vapor deposited (PVD) spectrally selective coatings for mid- and high-temperature solar thermal applications, Sol Energ Mat Sol C, 98 (2012) 1-23.

[15] H.C. Barshilia, P. Kumar, K.S. Rajam, A. Biswas, Structure and optical properties of Ag$\mathrm{Al}_{2} \mathrm{O}_{3}$ nanocermet solar selective coatings prepared using unbalanced magnetron sputtering, Sol Energ Mat Sol C, 95 (2011) 1707-1715.

[16] F. Cao, K. McEnaney, G. Chen, Z.F. Ren, A review of cermet-based spectrally selective solar absorbers, Energ Environ Sci, 7 (2014) 1615-1627.

[17] E. Cespedes, M. Wirz, J.A. Sanchez-Garcia, L. Alvarez-Fraga, R. Escobar-Galindo, C. Prieto, Novel Mo-Si3N4 based selective coating for high temperature concentrating solar power applications, Sol Energ Mat Sol C, 122 (2014) 217-225.

[18] H.C. Barshilia, N. Selvakumar, K.S. Rajam, A. Biswas, Structure and optical properties of pulsed sputter deposited $\mathrm{Cr}(\mathrm{x}) \mathrm{O}(\mathrm{y}) / \mathrm{Cr} / \mathrm{Cr}(2) \mathrm{O}(3)$ solar selective coatings, J Appl Phys, 103 (2008) 023507.

[19] H.C. Barshilia, N. Selvakumar, K.S. Rajam, D.V.S. Rao, K. Muraleedharan, A. Biswas, TiAlN/TiAlON/Si ${ }_{3} \mathrm{~N}_{4}$ tandem absorber for high temperature solar selective applications, Appl Phys Lett, 89 (2006) 191909.

[20] C.K. Ho, A.R. Mahoney, A. Ambrosini, M. Bencomo, A. Hall, T.N. Lambert, Characterizatio of Pyromark 2500 for High-Temperature Solar Receivers, in: ASME 2012 6th International Conference on Energy Sustainability \& 10th Fuel Cell Science, Engineering and Technology Conference ESFuelCell2012, San Diego, 2012. 
[21] C.K. Ho, A.R. Mahoney, A. Ambrosini, M. Bencomo, A. Hall, T.N. Lambert, Characterization of Pyromark 2500 Paint for High-Temperature Solar Receivers, J Sol EnergT ASME, 136 (2014) 14502.

[22] P. Campbell, M.A. Green, Light Trapping Properties of Pyramidally Textured Surfaces, J Appl Phys, 62 (1987) 243-249.

[23] H. Bender, J. Szlufcik, H. Nussbaumer, G. Palmers, O. Evrard, J. Nijs, R. Mertens, E. Bucher, G. Willeke, Polycrystalline Silicon Solar-Cells with a Mechanically Formed Texturization, Appl Phys Lett, 62 (1993) 2941-2942.

[24] C.F. Guo, T.Y. Sun, Y. Wang, J.W. Gao, Q. Liu, K. Kempa, Z.F. Ren, Conductive Black Silicon Surface Made by Silver Nanonetwork Assisted Etching, Small, 9 (2013) 2415-2419. [25] J. Moon, D. Lu, B. VanSaders, T.K. Kim, S.D. Kong, S. Jin, R. Chen, Z. Liu, High performance multi-scaled nanostructured spectrally selective coating for concentrating solar power, Nano Energy, 8 (2014) 238-246.

[26] C.F. Guo, T.Y. Sun, F. Cao, Q. Liu, Z.F. Ren, Metallic nanostructures for light trapping in energy-harvesting devices, Light-Sci Appl, 3 (2014).

[27] A. Bozzola, M. Liscidini, L.C. Andreani, Photonic light-trapping versus Lambertian limits in thin film silicon solar cells with 1D and 2D periodic patterns, Opt Express, 20 (2012) A224-A244.

[28] D.Y. Zhou, R. Biswas, Photonic crystal enhanced light-trapping in thin film solar cells, J Appl Phys, 103 (2008) 093102.

[29] S.B. Mallick, M. Agrawal, P. Peumans, Optimal light trapping in ultra-thin photonic crystal crystalline silicon solar cells, Opt Express, 18 (2010) 5691-5706.

[30] V.E. Ferry, M.A. Verschuuren, H.B.T. Li, E. Verhagen, R.J. Walters, R.E.I. Schropp, H.A. Atwater, A. Polman, Light trapping in ultrathin plasmonic solar cells, Opt Express, 18 (2010) A237-A245.

[31] H.A. Atwater, A. Polman, Plasmonics for improved photovoltaic devices, Nat Mater, 9 (2010) 205-213.

[32] C.M. Lampert, Coatings for Enhanced Photothermal Energy Collection .2. Non-Selective and Energy Control Films, Sol Energ Mater, 2 (1979) 1-17.

[33] C.K. Ho, J.E. Pacheco, Levelized Cost of Coating (LCOC) for Selective Absorber Materials in, Sandia National Laboratories, 2013.

[34] R.W. Bradshaw, D.B. Dawson, W.D.1. Rosa, R. Gilbert, S.H. Goods, M.J. Hale, P. Jacobs, S.A. Jones, G.J. Kolb, J.E. Pacheco, M.R. Prairie, H.E. Reilly, S.K. Showalter, L.L. Vant-Hull, Final Test and Evaluation Results from the Solar Two Project, in: J.E. Pacheco (Ed.), Sandia National Laboratories, 2002.

[35] C. Choudhury, H.K. Sehgal, Properties of Spray-Deposited Cobalt Oxide Selective Coatings on Aluminum and Galvanized Iron Substrates, Appl Energ, 10 (1982) 313-324.

[36] A.G. Avila, E.C. Barrera, L.A. Huerta, S. Muhl, Cobalt oxide films for solar selective surfaces, obtained by spray pyrolisis, Sol Energ Mat Sol C, 82 (2004) 269-278.

[37] C. Choudhury, H.K. Sehgal, Black Cobalt Selective Coatings by Spray Pyrolysis for Photothermal Conversion of Solar-Energy, Sol Energy, 28 (1982) 25-31.

[38] T. Maruyama, T. Nakai, Cobalt Oxide Thin-Films Prepared by Chemical VaporDeposition from Cobalt(Ii) Acetate, Sol Energ Mater, 23 (1991) 25-29.

[39] K.J. Cathro, Preparation of Cobalt-Oxide-Based Selective Surfaces by a Dip-Coating Process, Sol Energ Mater, 9 (1984) 433-447.

[40] G. Mcdonald, A Preliminary-Study of a Solar Selective Coating System Using a Black Cobalt Oxide for High-Temperature Solar Collectors, Thin Solid Films, 72 (1980) 83-87.

[41] K. Chidambaram, L.K. Malhotra, K.L. Chopra, Spray-Pyrolyzed Cobalt Black as a HighTemperature Selective Absorber, Thin Solid Films, 87 (1982) 365-371. 
[42] H. Sai, Y. Kanamori, K. Arafune, Y. Ohshita, M. Yamaguchi, Light trapping effect of submicron surface textures in crystalline Si solar cells, Prog Photovoltaics, 15 (2007) 415423.

[43] C. Lin, J.A. Ritter, B.N. Popov, Characterization of sol-gel-derived cobalt oxide xerogels as electrochemical capacitors, J Electrochem Soc, 145 (1998) 4097-4103.

[44] S.R. Mishra, I. Dubenko, J. Losby, K. Ghosh, M. Khan, N. Ali, Anomalous magnetic properties of mechanically milled cobalt oxide nanoparticles, J Nanosci Nanotechno, 5 (2005) 2076-2081.

[45] H.M. Yang, Y.H. Hu, X.C. Zhang, G.Z. Qiu, Mechanochemical synthesis of cobalt oxide nanoparticles, Mater Lett, 58 (2004) 387-389.

[46] L.J. Cote, A.S. Teja, A.P. Wilkinson, Z.J. Zhang, Continuous hydrothermal synthesis and crystallization of magnetic oxide nanoparticles, J Mater Res, 17 (2002) 2410-2416.

[47] A.M. Cao, J.S. Hu, H.P. Liang, W.G. Song, L.J. Wan, X.L. He, X.G. Gao, S.H. Xia, Hierarchically structured cobalt oxide $\left(\mathrm{Co}_{3} \mathrm{O}_{4}\right)$ : The morphology control and its potential in sensors, J Phys Chem B, 110 (2006) 15858-15863.

[48] M. Chen, B. Hallstedt, L.J. Gauckler, Thermodynamic assessment of the Co-O system, J Phase Equilib, 24 (2003) 212-227.

[49] V.R. Shinde, S.B. Mahadik, T.P. Gujar, C.D. Lokhande, Supercapacitive cobalt oxide $\left(\mathrm{Co}_{3} \mathrm{O}_{4}\right)$ thin films by spray pyrolysis, Appl Surf Sci, 252 (2006) 7487-7492.

[50] J.M. Lata, M. Rodriguez, M.A. de Lara, High flux central receivers of molten salts for the new generation of commercial stand-alone solar power plants, J Sol Energ-T ASME, 130 (2008) 021002.

[51] S.W. Boettcher, E.L. Warren, M.C. Putnam, E.A. Santori, D. Turner-Evans, M.D. Kelzenberg, M.G. Walter, J.R. McKone, B.S. Brunschwig, H.A. Atwater, N.S. Lewis, Photoelectrochemical Hydrogen Evolution Using Si Microwire Arrays, J Am Chem Soc, 133 (2011) 1216-1219.

[52] V.V. Iyengar, B.K. Nayak, M.C. Gupta, Optical properties of silicon light trapping structures for photovoltaics, Sol Energ Mat Sol C, 94 (2010) 2251-2257.

[53] H.P. Yoon, Y.A. Yuwen, C.E. Kendrick, G.D. Barber, N.J. Podraza, J.M. Redwing, T.E. Mallouk, C.R. Wronski, T.S. Mayer, Enhanced conversion efficiencies for pillar array solar cells fabricated from crystalline silicon with short minority carrier diffusion lengths, Appl Phys Lett, 96 (2010) 213503.

[54] J.M. Ha, S.H. Yoo, J.H. Cho, Y.H. Cho, S.O. Cho, Enhancement of antireflection property of silicon using nanostructured surface combined with a polymer deposition, Nanoscale Res Lett, 9 (2014) 9.

[55] G. Willeke, H. Nussbaumer, H. Bender, E. Bucher, A Simple and Effective Light Trapping Technique for Polycrystalline Silicon Solar-Cells, Sol Energ Mat Sol C, 26 (1992) 345-356.

[56] S.E. Han, G. Chen, Toward the Lambertian Limit of Light Trapping in Thin Nanostructured Silicon Solar Cells, Nano Lett, 10 (2010) 4692-4696.

[57] P.R. Athey, F.K. Urban, M.F. Tabet, W.A. McGahan, Optical properties of cobalt oxide films deposited by spray pyrolysis, J Vac Sci Technol A, 14 (1996) 685-692.

[58] S. Chu, A. Majumdar, Opportunities and challenges for a sustainable energy future, Nature, 488 (2012) 294-303.

[59] C.K. Ho, B.D. Iverson, Review of high-temperature central receiver designs for concentrating solar power, Renew Sust Energ Rev, 29 (2014) 835-846.

[60] N. Birks, G.H. Meier, F.S. Pettit, Introduction to the High Temperature Oxidation of Metals, 2nd ed., Cambridge University Press, 2006. 
Figure 1. Cobalt oxide nanopowders characterization: (a) SEM image of as-synthesized powders and (b) X-ray diffraction pattern of Co oxide powders after stabilizing at $750^{\circ} \mathrm{C}$ for 2 hours, showing the $\mathrm{Co}_{3} \mathrm{O}_{4}$ phase

Figure 2. (a) Schematic diagram of $\mathrm{Co}_{3} \mathrm{O}_{4}$ light absorbing coating structure and (b) photographs of a sand blasted Inconel-625 substrate and a $\mathrm{Co}_{3} \mathrm{O}_{4}$ coated sample (designated as $\mathrm{Co}_{3} \mathrm{O}_{4}-1$ sample).

Figure 3. SEM images of (a) $\mathrm{Co}_{3} \mathrm{O}_{4}$ coating (scale bar : $5 \mu \mathrm{m}$ ) and (b) $\mathrm{Co}_{3} \mathrm{O}_{4}$ coating layer with $3 \mu \mathrm{m}$ hole patterns (scale bar : $5 \mu \mathrm{m}$, inset, $20 \mu \mathrm{m}$ ) and the reflectance in the visible and NIR range of the two samples.

Figure 4. SEM images of (a) $\mathrm{Co}_{3} \mathrm{O}_{4}-2$ (vol. ratio= $=1\left(\mathrm{CO}_{3} \mathrm{O}_{4}\right): 3$ (polymer beads), see Table 1) coating (scale bar : $5 \mu \mathrm{m})$ and $(\mathrm{b}) \mathrm{Co}_{3} \mathrm{O}_{4}-3\left(\right.$ vol. ratio $=1\left(\mathrm{Co}_{3} \mathrm{O}_{4}\right): 5$ (polymer beads) $)$ coating layer (scale bar $=$ $5 \mu \mathrm{m})$ and the reflectance in the visible and NIR range of $\mathrm{Co}_{3} \mathrm{O}_{4}-1, \mathrm{Co}_{3} \mathrm{O}_{4}-2$ and $\mathrm{Co}_{3} \mathrm{O}_{4}-3$ samples.

Figure 5. (a,b) SEM image of $\mathrm{Co}_{3} \mathrm{O}_{4}$ coating after annealing at $750^{\circ} \mathrm{C}$ for 1,000 hours (scale bar: (a) 5 $\mu \mathrm{m}$ and (b) $1 \mu \mathrm{m}$ ) and (c) XRD patterns of Co oxides, as-made (black), after $750^{\circ} \mathrm{C}$ exposure for 100 hrs (red) and $1000 \mathrm{hrs}$ (blue), showing no phase degradation after the annealing.

Figure 6. TGA analysis results on $\mathrm{Co}_{3} \mathrm{O}_{4}$ nanopowders with temperature ramping rate of $20^{\circ} \mathrm{C} / \mathrm{min}$ followed by holding at $750^{\circ} \mathrm{C}$ for 2 hours under air-flowing. The initial weight gain is presumably due to the full conversion of residual $\mathrm{CoO}$ to $\mathrm{Co}_{3} \mathrm{O}_{4}$, after which the weight gain is essentially zero, showing the stability of the $\mathrm{Co}_{3} \mathrm{O}_{4}$ nanopowders. 
Figure 7. Figure of merit of two samples of $\mathrm{Co}_{3} \mathrm{O}_{4}-3$ described in Table1 as a function of exposure time (up to 1000 hours) at $750^{\circ} \mathrm{C}$ in air. 
Figure 1
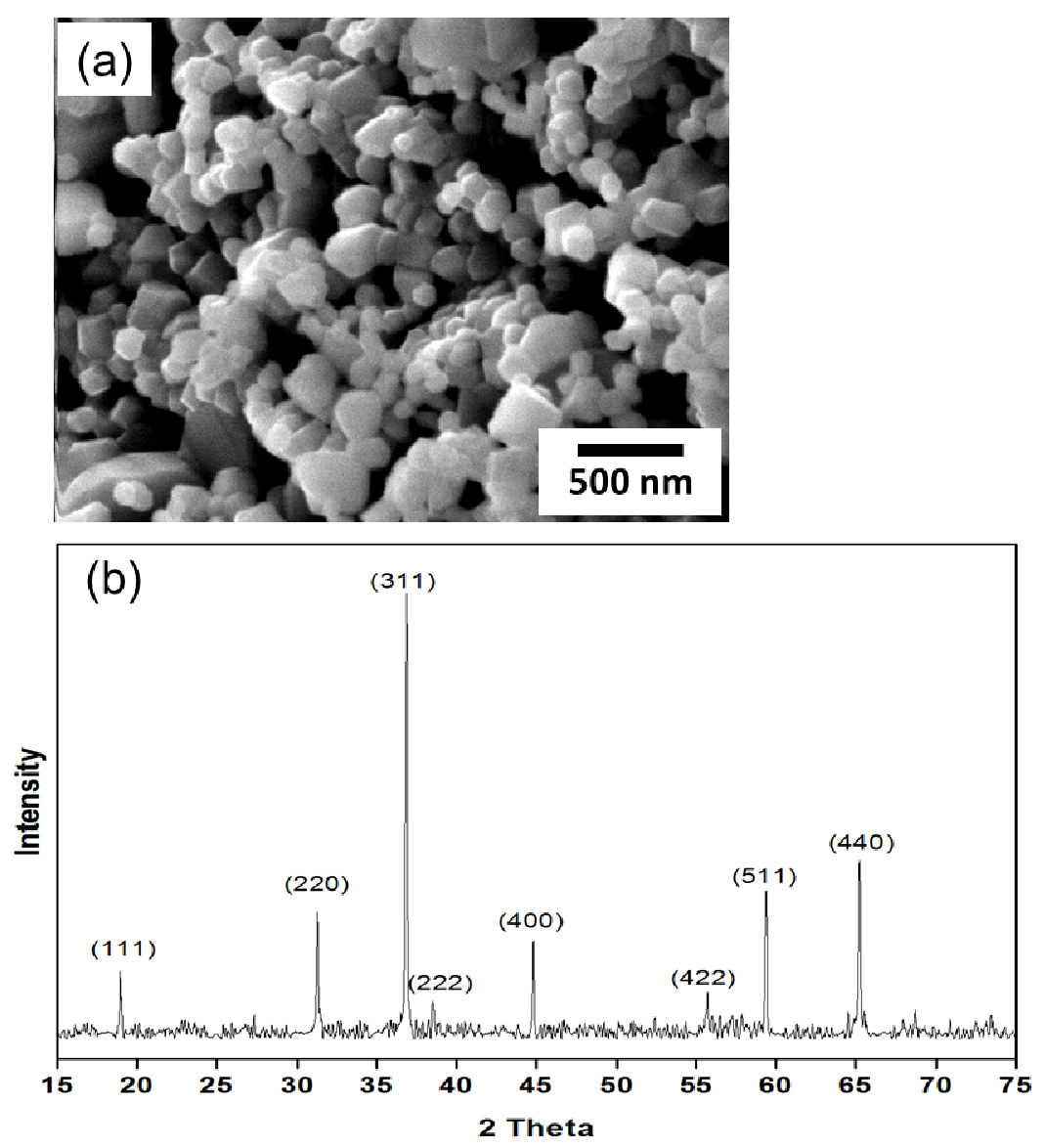
Figure 2

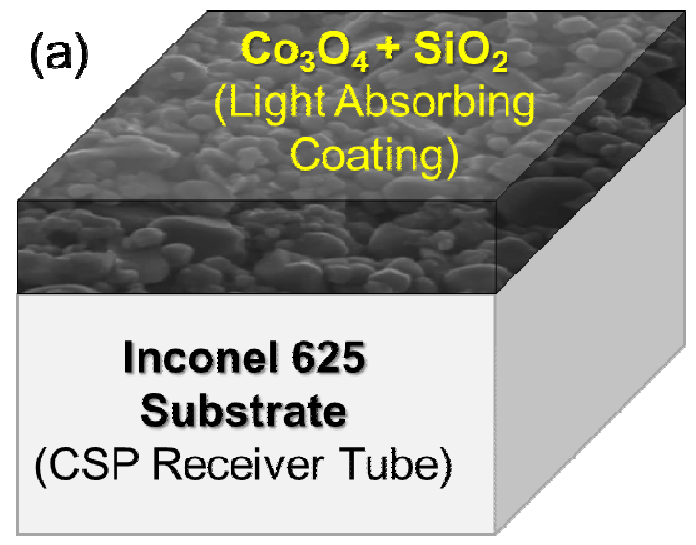

(b)

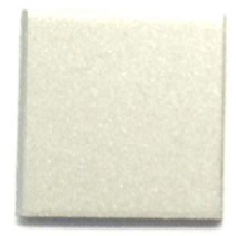

Sand blasted Inconel 625 substrate

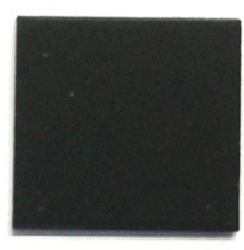

$\mathrm{Co}_{3} \mathrm{O}_{4}$ coated sample 
Figure 3

(a)

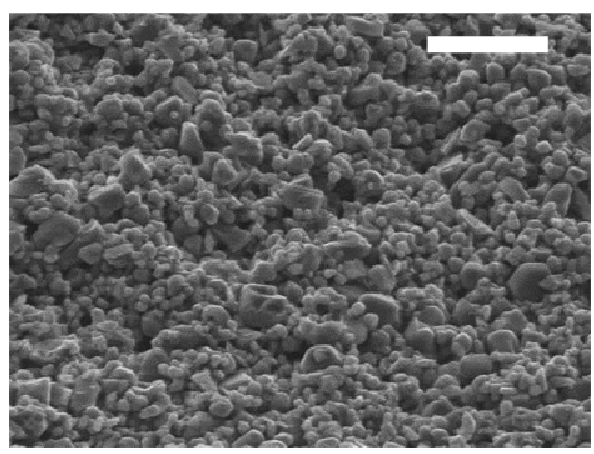

(b)

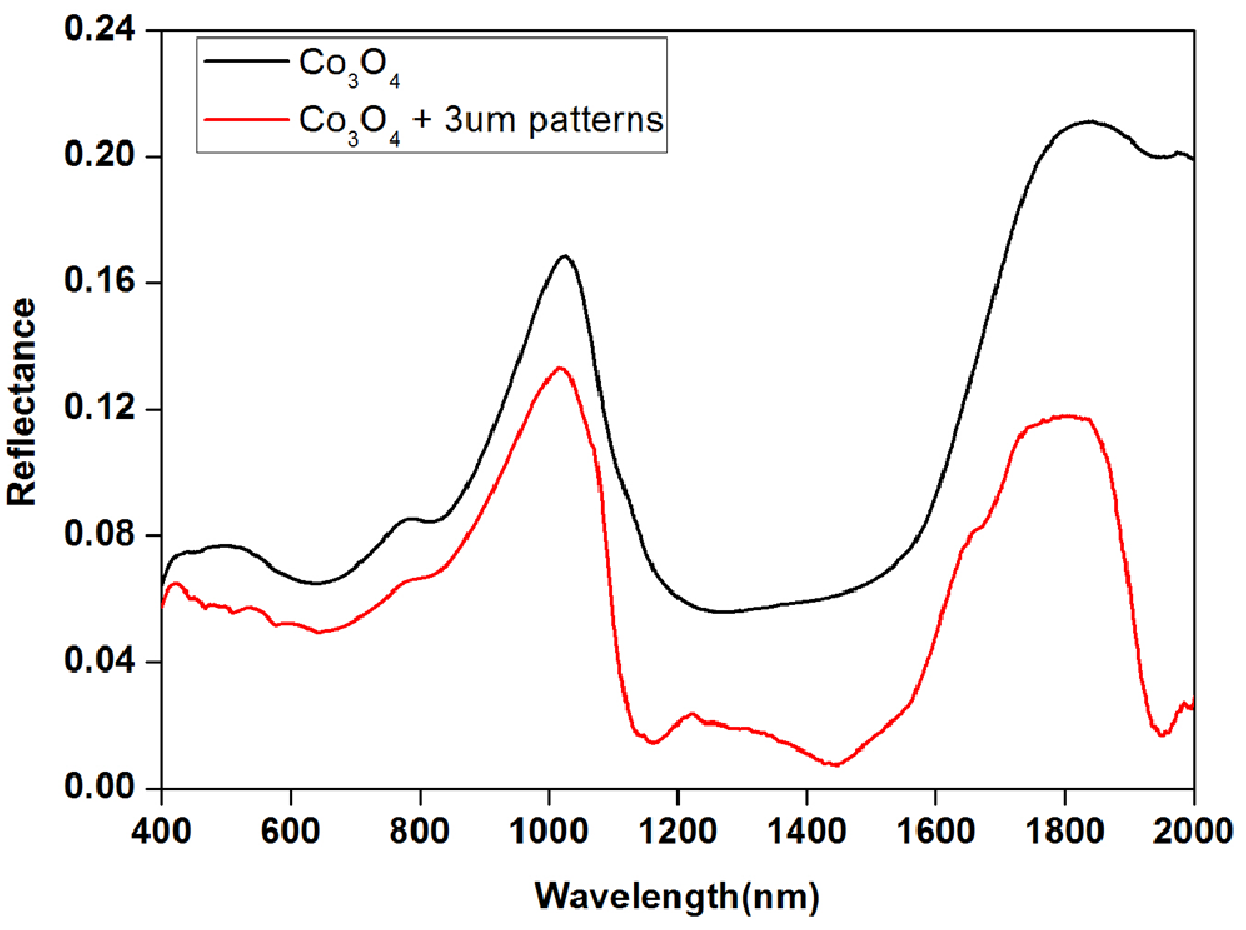


Figure 4

(a)

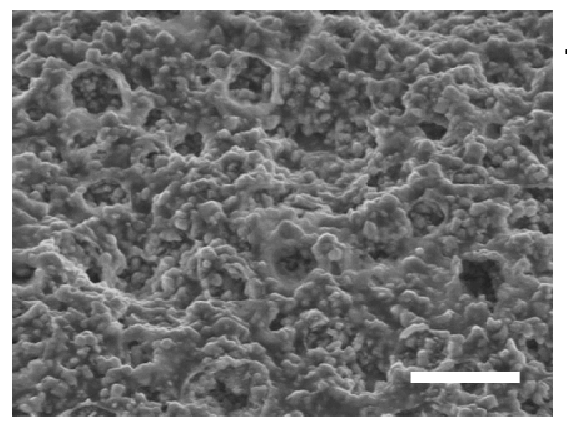

(b)

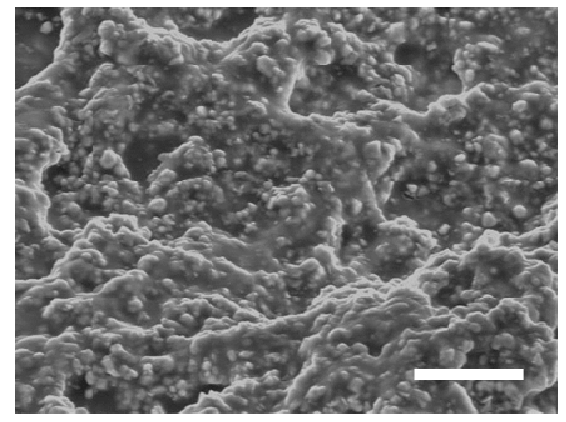

(c)

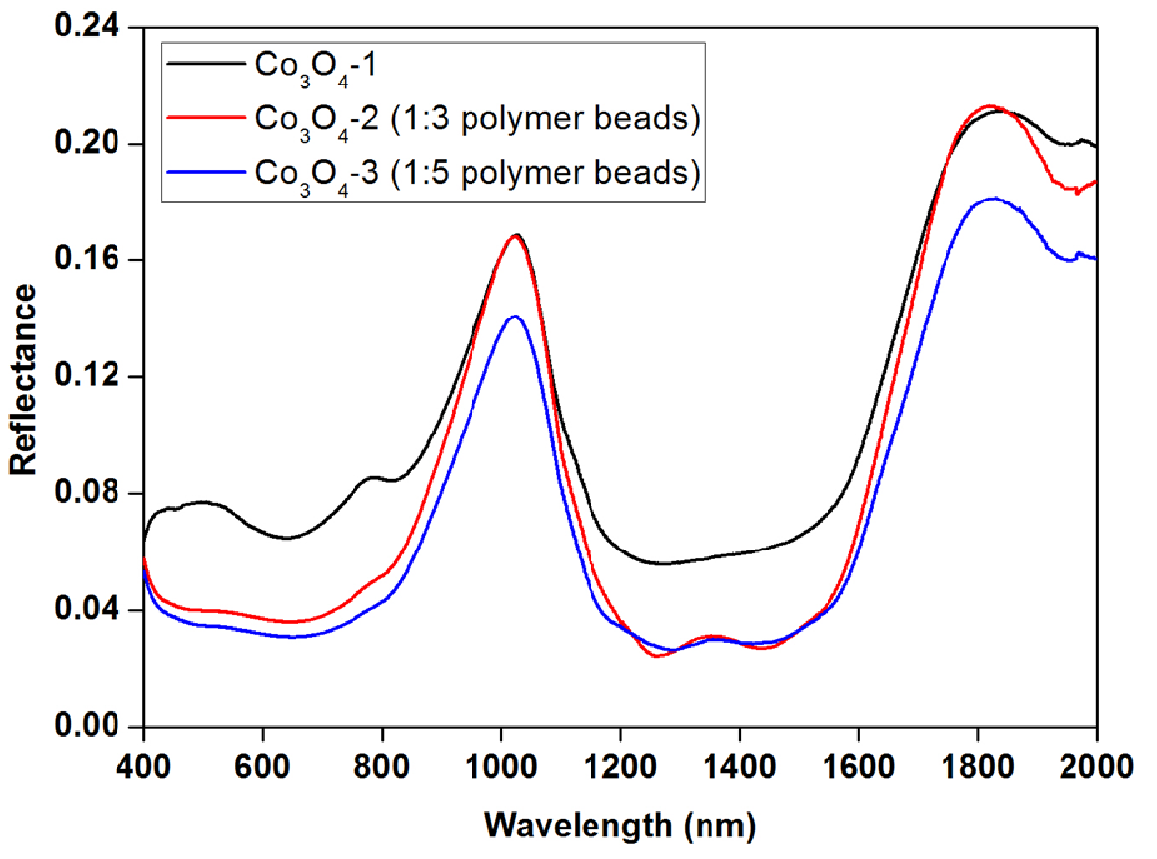


Figure 5

(a)

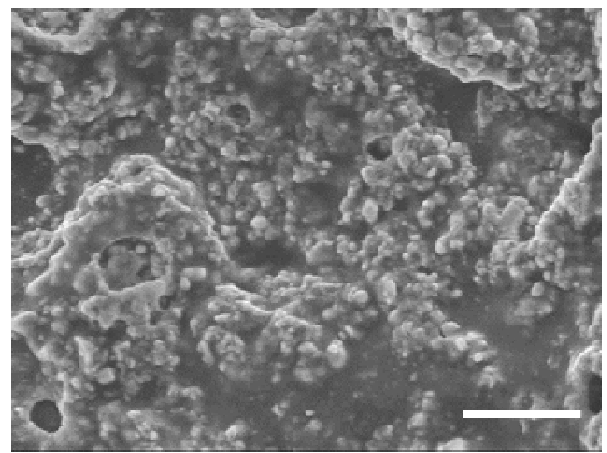

(b)
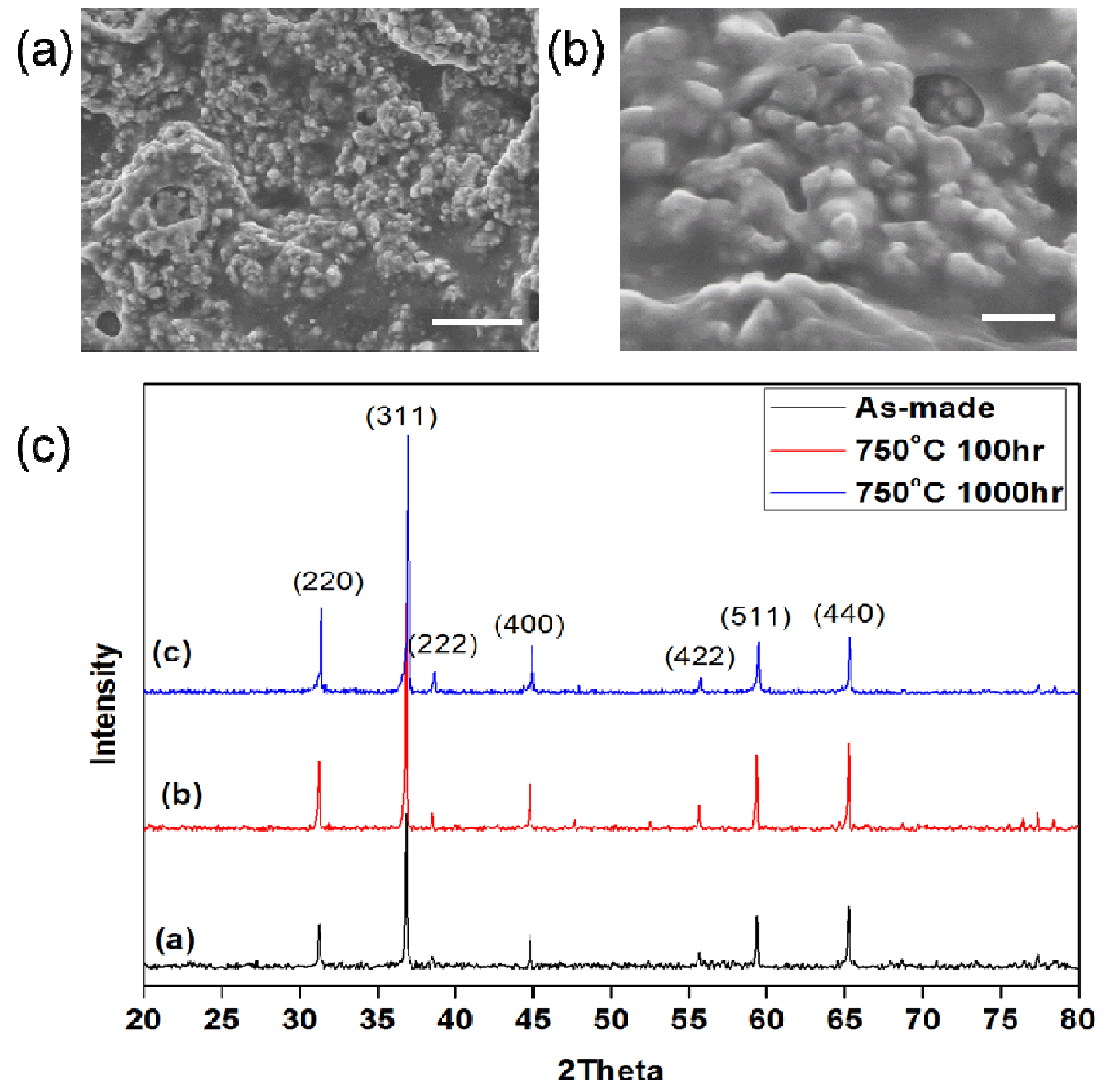
Figure 6

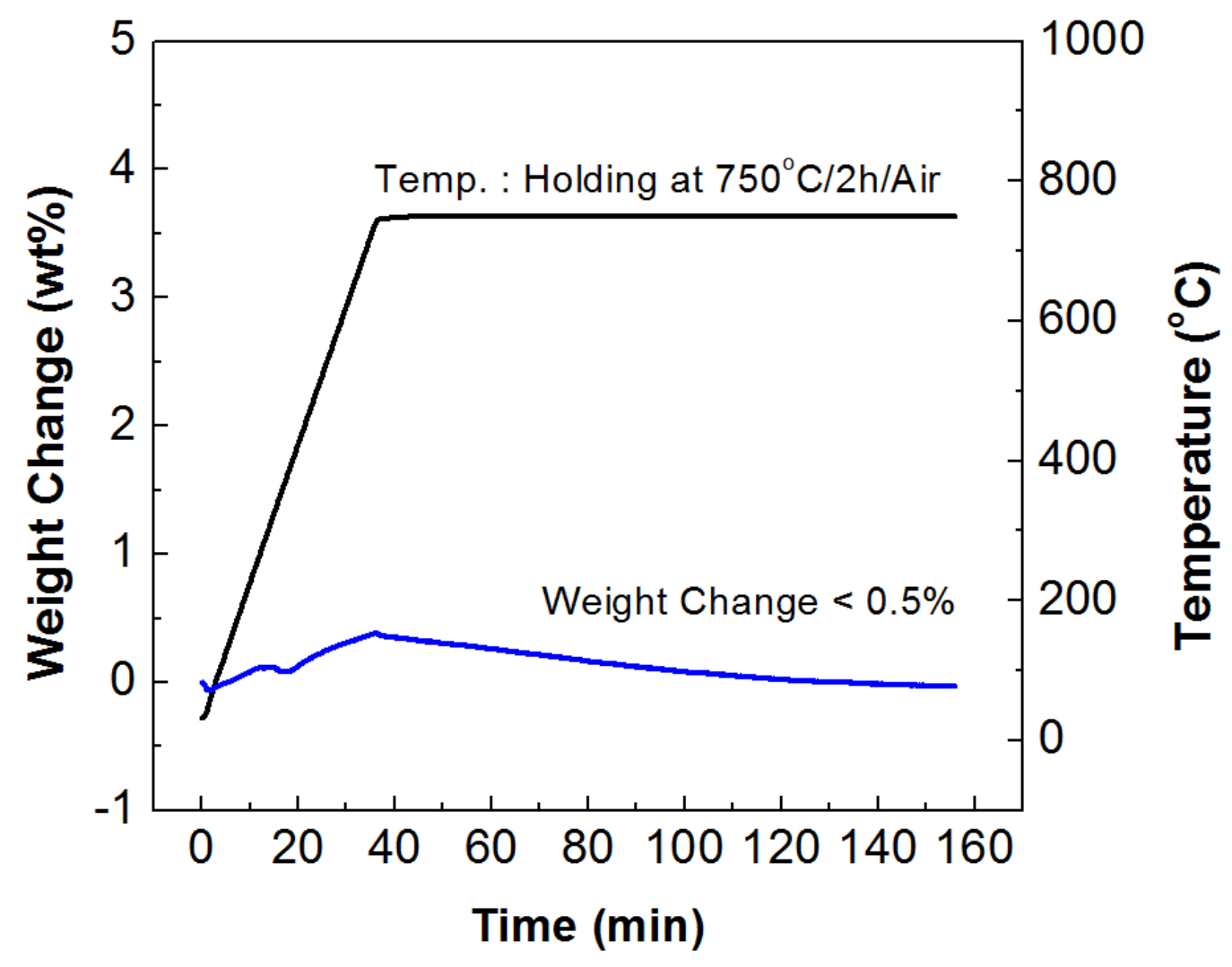


Figure 7

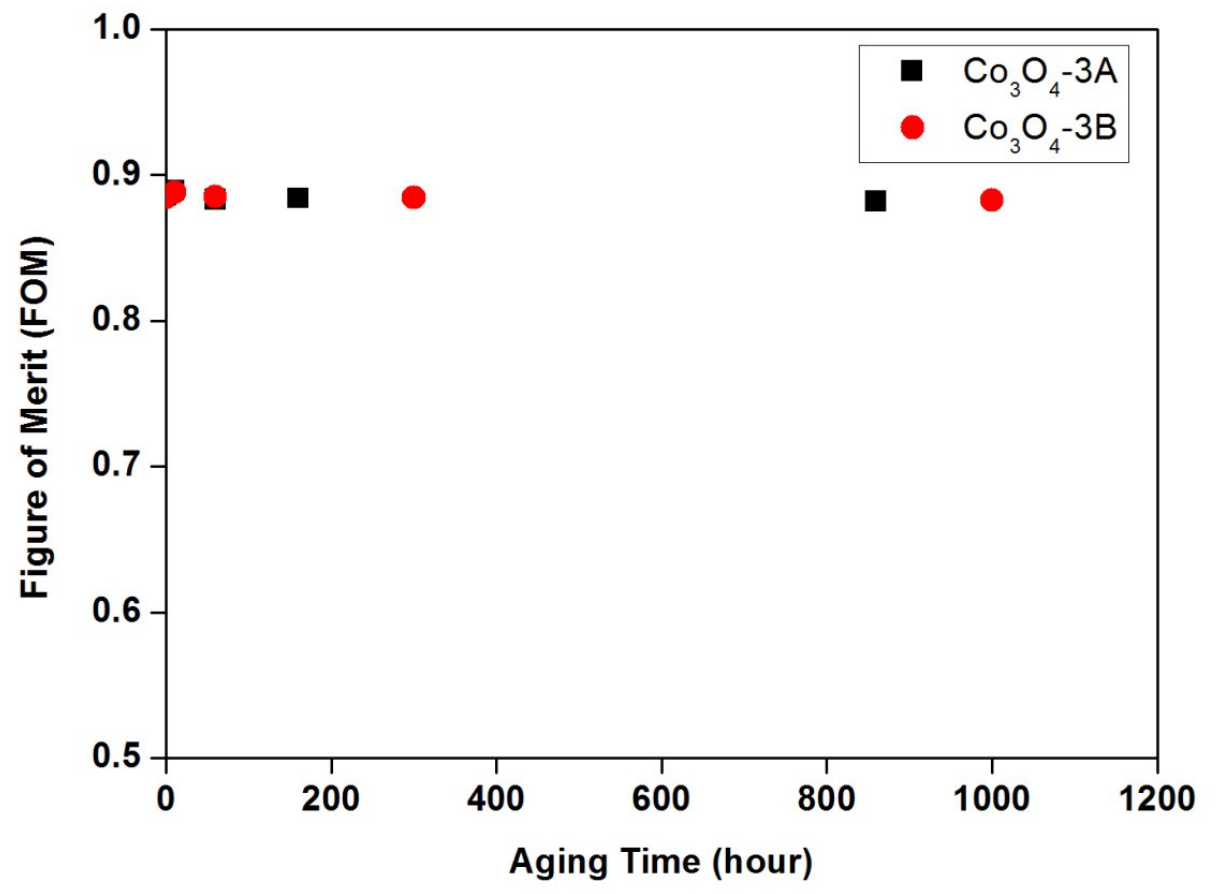


Table 1. Sample fabrication condition and figure of merits(FOM)

\begin{tabular}{|c|c|c|c|c|}
\hline \multirow[b]{2}{*}{$\begin{array}{l}\text { Sample } \\
\text { Name }\end{array}$} & \multicolumn{3}{|c|}{ Volume ratio } & \multirow[b]{2}{*}{$\begin{array}{c}\text { FOM } \\
\text { (Figure of merits) }\end{array}$} \\
\hline & $\begin{array}{c}\mathrm{Co}_{3} \mathrm{O}_{4} \\
\text { nanopowders }\end{array}$ & $\begin{array}{c}\mathrm{SiO}_{2} \text { dielectric } \\
\text { matrix }\end{array}$ & $\begin{array}{l}\text { Polystyrene } \\
\text { polymer beads }\end{array}$ & \\
\hline $\mathrm{CO}_{3} \mathrm{O}_{4}-1$ & 1 & 1.5 & 0 & 0.854 \\
\hline $\mathrm{CO}_{3} \mathrm{O}_{4}-2$ & 1 & 4.5 & 3 & 0.877 \\
\hline $\mathrm{Co}_{3} \mathrm{O}_{4}-3$ & 1 & 6.5 & 5 & 0.882 \\
\hline
\end{tabular}

